\title{
OUTPUT CHANGES AND INFLATIONARY BIAS IN TRANSITION
}

\author{
RANDALL K. FILER ${ }^{*}$ and JAN HANOUSEK ${ }^{* *}$
}

ABSTRACT: Mismeasurement of inflation is likely to be more severe in a transition economy than in a more stable environment. Reasonable estimates of the size of the inflationary bias in the Czech Republic suggest that conventionally reported declines in real output and living standards during the transition may be a statistical artifact rather than a real phenomenon.

ABSTRAKT: Dá se očekávat, že v období přechodu od plánované k tržní ekonomice budeme pozorovat daleko větší chyby v měření inflace než je tomu v zemích se stabilní tržní ekonomikou. Naše odhady pro vychýlení měřené inflace v České republice naznačují, že všemi zdůrazňovaný pokles reálného produktu a životních standardů během období transformace odráží spíše statistický artefakt než ekonomickou realitu.

\author{
JEL CODES: $\quad$ C8, E3, P2
}

KEYWORDS: $\quad$ Inflation, Transition, Bias, GDP growth

\footnotetext{
* Hunter College and The Graduate Center, City University of New York, NY, USA, e-mail: rfiler@ hunter.cuny.edu; ** corresponding author: CERGE-EI, a joint workplace of Charles University and The Academy of Sciences of the Czech Republic, Politických vězňů 7, 11121 Prague 1, Czech Republic, e-mail: jan.hanousek@cerge.cuni.cz. This research was supported in part by grants P97-8119-R from the PHARE/ACE program of the European Union and II/75831 from the Volkswagen Foundation.
} 


\section{Introduction}

A substantial decline in real output, the so-called "transition recession," is one of the most widely accepted stylized facts about the transition from communism to market economies in Central and Eastern Europe. In its summary of the first ten years of transition, the European Bank for Reconstruction and Development (EBRD) claimed that "all countries faced .... falling output" and that "the severity of the initial recession came as a surprise to most analysts of the region" (EBRD [1999, p. 57]). Gros and Steinherr (1996, p. 278) summarized the situation by saying that "one of the most visible developments that resulted from this configuration of shocks and policies in the early 1990s was a steep decline in output." This apparent output decline is easily seen when examining official GDP figures from transition economies, as plotted in Figure 1.

There are, however, many reasons to question the extent or even the existence of the reported output decline. First, managers in planned economies had incentives to overstate production to meet the plan, while in market economies the incentives are to under-report output to reduce taxes. Moreover, statistical offices in transition countries were not able to identify newly-established private firms that often operated in the grey market (for a discussion, see De Broeck and Koen [2000]). Finally, and perhaps most importantly, reported inflation may overstate actual inflation, thereby under-reporting real output. In this paper we show that even modestly overstating the rate of inflation during the decade of the 1990s may have significantly altered perceptions of growth in the postcommunist countries.

Despite their potential importance, possible biases in inflation have received very little 
attention in the extensive literature dealing with transition countries. ${ }^{1}$ The EBRD Transition Report (1999) is typical of most analyses: it spends at most a paragraph pointing out that official output figures are usually an underestimate of the true level before spending several pages asking, why was the recession so severe across the region? In what follows we will show that if inflation measures during the transition are even moderately biased, there may be reason to question the very existence of the transition recession. Furthermore, even modest biases in inflation would have significant policy implications. Many years of apparent decline in real GDP were probably growth years. In addition, real wages have been higher than believed, with correspondingly lower poverty rates. Thus, governments have more latitude to lower social spending, thereby reducing tax burdens and increasing growth. Implications for integration with the European Union are similarly profound. If removing the upward bias in inflation adjustment, results in GDP and growth being higher than commonly believed, there will be a lower need for structural assistance, enabling more rapid expansion of the Union. In addition, smaller differences in real standards of living mean that there is less reason for concern over adopting free labor mobility.

Figure 2 shows the relationship between inflation and real output growth for several transition countries between 1991 and 1997. Higher inflation is clearly associated with lower growth in the same time period. Although it is conceivable that the negative

\footnotetext{
${ }^{1}$ Exceptions are Lipton and Sachs (1990), Winiecki (1991), Koen (1995) and Kornai (1997). In an otherwise excellent summary of inflation during the transition, Koen and De Masi (1997) provide only a cursory footnote that "Price indices continued to suffer from many biases well into transition. The data shown in this paper should therefore be interpreted as indicative...."
} 
in Figure 2 is immune to including either fixed or random country effects that should absorb any differences in the skill with which the transition was managed (or in initial conditions) across countries. ${ }^{2}$ We are left with the hypothesis that measurement errors causing upward biases in inflation have created downward biases in GDP measures, making the measured transition recession appear more severe than the actual economic decline. ${ }^{3}$

Even in stable market economies, consumer price indices are biased upward. A recent highlevel commission appointed by the U.S. Congress concluded that the U.S. CPI overstated the rate of inflation during the 1990s by about one-third (i.e. 1.1 percentage points out of an average annual rate of 3 percent) (Boskin et. al [1996]). Similar results exist for the U.K. (Oulton [1996]), Sweden (Dahlen [1994]), Australia (Woolford [1994]) and Germany (Hoffmann [1999]). Transition economies have faced substantially greater rates of inflation than the countries in these studies. Between 1990 and 1999 the cumulative increase in reported prices was $290 \%$ in the Czech Republic, $635 \%$ in Hungary, 6,200\% in Poland, 80,500\% in Romania, 177,500\% in Bulgaria, 1,590,000\% in Russia and 16,870,000\% in Ukraine. It is doubtful whether newly established or reformed statistical offices were able to measure inflation at these levels with anywhere near the precision required to meaningfully interpret real economic variables.

\footnotetext{
${ }^{2}$ Results are presented at http://home.cerge.cuni.cz/hanousek/inflation 1.

${ }^{3}$ In the long run economies with greater inflation may generate lower rates of investment and eventual growth (see Gylfason and Herbertsson [1996] and Bruno and Easterly [1998]), but such a relationship could not have appeared in the initial years of transition.
} 


\section{Sources of bias in inflation measures and possible magnitudes in the Czech Republic}

As is well understood, the main sources of bias in measures of inflation are (1) consumer substitution, (2) outlet substitution, (3) quality improvement, and (4) new goods. There are strong reasons to believe that each of these sources of bias will be more significant in a transition environment than it is in stable economies such as the U.S'. Following Diewert (1998), ${ }^{4}$ we present below approximations of these biases for 1996 and 1997 in the Czech Republic, the transition country with the lowest inflation rate and the most advanced economy. It is to be anticipated that biases in other countries in the region, with less stable economies and less welldeveloped statistical offices, or in earlier years in the Czech Republic, when distortions and inflation rates were greater, are substantially greater than the levels we find probable for the Czech Republic during late transition. Thus, our estimates should be considered a lower bound on the extent of bias across the full transition experience.

Consumer Substitution Bias occurs because prices of goods and services increase at different rates. Given this divergence, consumers revise their consumption patterns, substituting commodities with relatively low price increases for those whose prices rose faster. Koen and De Masi (1997) show that the inter-year correlation between prices of various items in the CPI basket for every transition economy is substantially lower than that for stable economies such as the United States'. This suggests that the potential for consumer substitution bias is correspondingly much larger in these economies. Conventional inflation measures exclude such substitution by using fixed base-period weights. An appropriate cost of living measure, however, should not ask the increase in income required to purchase a fixed bundle of goods, but rather, the increase required to maintain a constant utility level (see Könus [1939] and Pollak [1981]). Diewert (1976) has shown that this true cost of living index lies between the Laspeyres and Paasche (end-period weighted) indices. Indeed, the best approximation may be Fisher's (1922) ideal price index, the geometric mean of the Laspeyres and Paasche

\footnotetext{
${ }^{4}$ All approximation formulae used below and the underlying assumptions required for their use are taken directly from Diewert (1998). Specific values for the Czech Republic and interpretation are ours.
} 
indices.

With Cobb-Douglas consumer preferences and a Taylor series approximation for the Fisher index, the bias between the Laspeyres and Fisher ideal price indices can be approximated:

$$
P_{L}-P_{F}=.5(1+I) \operatorname{Var}(r),
$$

where $I$ is the Laspeyres measure of inflation and $\operatorname{Var}(r)$ is the variance of relative price increases across commodities. ${ }^{5}$

In 1996 and 1997 prices in the Czech Republic rose by 8.8\% and 8.5\%. The standard deviations of the price changes across the 750 items in the CPI basket were $15.1 \%$ and $11.9 \%$ respectively. If the above assumptions are correct, this suggest that the upward bias in the CPI might have been about 1.24 percentage points for 1996 and 0.77 percentage points for 1997.

Outlet Substitution Bias occurs when new, less expensive distribution channels are excluded by resampling from the same outlets as in the base period. When discount outlets are increasing in importance, this bias will be

$$
B_{D}=(1+I) s d,
$$

where $s$ is the increase in the share of discount stores and $d$ is the average percentage discount in such stores. During the past decade shopping malls, supermarkets, and hypermarkets have increasingly replaced small local stores in transition economies. Conservative assumptions that such stores increase their share of the market

${ }^{5}$ Cobb-Douglas utility functions with coefficients summing to one are required to ensure constant expenditure shares (see Diewert [1995, p. 18]). Lloyd (1975) presents a more general formula based on a two-level CES consumption function and concludes that "the magnitude of biases due to the neglect of commodity substitution... may be significant" (p. 309) and that they are "an increasing function of the elasticities of intergroup substitution, the elasticities of intragroup substitution [and] the change in the relative prices of individual commodities" (p. 308). Simulations in Lloyd (Table 2) suggest a bias on the order of magnitude of $10 \%$ using much lower variation in relative prices and elasticities of substitution than are found in the Czech Republic during transition (see Banse and Brosig [1998]). Thus, if we were to recalculate potential biases using a two-level CES function and Czech data, the implied biases would be substantially larger than those suggested from the CobbDouglas form adopted by Diewert. We retain the lower estimate both in order to be consistent with the paper we are using as a model and to establish that our conclusions hold even under exceptionally conservative assumptions. 
by 4 percent annually and sell for 15 percent less than conventional shops ${ }^{6}$ result in an annual bias in the CPI of about 0.69 percentage points at average Czech inflation rates during the 1990 s of $14.5 \%$ a year and 0.65 and 0.66 percentage points in 1996 and 1997 specifically.

Quality Improvement Bias occurs when statistical agencies attribute to inflation part of a price increase due to improved quality instead. Quality improvements are pervasive in transition economies, largely because of low initial quality levels. Easier measurement of quantity rather than quality meant managers in command economies economized on effort and other resources by reducing quality while meeting quantity goals for imprecisely specified "goods" (Stiglitz [1994]). In 1993, a jar of Czech cherry jam had pits in the cherries and a pry-off top that could not reseal the jar. A few years later a jar of jam from the same producer had pitted cherries and a screw-off top. How much of the higher price should be attributed to inflation and how much to the fact that jam without pits is a better product? Similarly, when the Czech auto maker Skoda introduced the first model based entirely on technology from its new parent Volkswagen, the Czech statistical office adjusted quality upwards by approximately 5 percent due to the new model being 5 percent heavier than its predecessor. Such a minor adjustment seems inconsistent with the fact that the two cars were both available for sale at the same time with market prices that differed by some 50 percent. Similar uncaptured quality improvements exist in almost all of the items in the reference basket in transition economies. A rough estimate of the extent of quality improvement bias in a Laspeyres index is

$$
B_{Q}=[(1+I) m q] /(1+q)
$$

where $m$ is the fraction of products replaced by improved models and $q$ is the percentage increase in the quality (price consumers are willing to pay) not accounted for. If only 10 percent of the consumer basket improves in quality by 10 percent in a given year (very conservative estimates given the massive changes in the region and the crude level of aggregation in the consumer basket), the upward bias in inflation measures in the Czech

\footnotetext{
${ }^{6}$ A casual empirical estimate by one of the authors showed that his weekly grocery and household operating basket was over $20 \%$ less expensive at a Tesco hypermarket than it was in the traditional shop in his neighborhood that continued to exist from communist days.
} 
Republic is about 1.0 percentage point annually.

New Goods Bias occurs because of the delay between when new goods enter a market and when they are included in the CPI. The Czech consumer bundle was last reweighted in 1993. Goods that appeared or increased in share since 1993 have been underweighted. Since prices typically fall at the beginning of a product's life cycle, this results in underweighting products with falling prices and overstating of inflation. Roughly, this bias is

$$
B_{N}=.5(1+I) n f
$$

where $n$ is the extent of underweighting of new goods and $f$ is the average fall in the price of these goods during the period. Given the rapid opening of former communist economies to world markets, "new" goods are far more common than in the West. Since we do not possess country specific data on new goods or reservation prices, however, we conservatively adopt Diewert's assumptions (1998) for the U.S. that new goods constitute 5 percent of the basket and sell on average for 20 percent less than their reservation price. This yields an estimate of new goods bias, at Czech inflation rates, of about 0.55 percentage points.

\section{Implications for measured growth during transition}

Taken together, these four sources of bias suggest that, instead of $8.8 \%$ for 1996 and $8.5 \%$ for 1997 , true inflation rates for the Czech Republic were probably closer to 5.3\% and 5.5\%. Thus, reported growth rates of $4.8 \%$ for 1996 and $-1.0 \%$ for 1997 may have been closer to $8.3 \%$ and $1.8 \%$.

These figures are obviously only suggestive. We have added the sources of bias and neglected second order interaction effects among them. We have also calculated the extent of the bias for two recent years when the Czech economy was relatively stable. If we had data available for the earlier years in the transition, we would have found that the extent of the bias was substantially greater due to the significantly larger variance 
in relative price changes. ${ }^{7}$ We believe that the assumptions used are very conservative, especially with respect to the extent of quality improvement and new product introduction. Thus, we believe that measured rates of inflation have been grossly overstated and, therefore, that GDP levels and growth rates have been correspondingly understated throughout the transition.

Recently, however, the order of magnitude of the possible bias we suggest exists for the Czech Republic has been criticized as implying an unreasonably high rate of productivity growth. Brada, King and Kutan (2000) estimate the following equation (taken from [Dornbusch and Fischer (1993)]):

$$
A P P I=\alpha(A w / w)+(1-\alpha)(A e / e)+Y
$$

where

$$
\begin{array}{ll}
P P I & =\text { producer price index } \\
w & =\text { nominal wages } \\
e & =\text { nominal exchange rate (domestic per foreign) } \\
Y & =\text { productivity shock }
\end{array}
$$

Brada et al. substitute a quadratic time trend for the productivity shock and further assume that all PPI increases are fully passed through to the CPI. They then argue that any difference between the CPI and PPI should be a function of the change in real wages, interest rates, and productivity shocks in the retail sector. Using quarterly data for the Czech Republic for 1993 through 1998 they find an implied rate of productivity growth of almost 8 percent per year in 1995-1996, although less in other years. They then argue that, while 8 percent annual productivity growth seems plausible, “...if we accept Filer and Hanousek’s upper estimate of the price-index bias of 50 percent, real annual productivity shocks would have to be adjusted upwards by as much as almost 5 percentage points..." an amount they feel intuitively, although without evidence, is

\footnotetext{
${ }^{7}$ This contrasts with the Boskin commission's findings for the U.S., which suggest that the bias in percentage points is relatively constant across different levels of inflation. Of course, such findings hold with respect to an economy that did not exhibit the massive price distortions and need for relative price adjustments found at the beginning of the transition.
} 
"unrealistic."

We find this analysis unconvincing. There is no underlying justification presented for the equation estimated. Dornbusch and Fischer explicitly justify the equation on the assumption that all firms engage in cost-based pricing as well as an exchange rate rule that explicitly reflects only current and past inflation. Thus, it is unclear what role such an equation can serve in a transition environment where exchange rates are either fixed and largely determined by capital inflows and where a large part of price behavior occurs through gradual removal of disequilibrium-level regulated prices. Consider as examples the housing and energy markets, where there is no reason to believe that price increases resulting from changes in regulated rents and electricity (or coal and oil) prices ${ }^{8}$ are in any way determined by either wage increases or exchange rate movements. Thus, we are unsure whether the Dornbusch-Fischer equation tells us anything about productivity shocks in a transition environment. If the case revolves around an appeal to intuition, then to assume that statistical agencies in the transition are able to do a better job of eliminating bias than those in stable market economies such as the U.S. or the U.K. seems even more unrealistic. We also note that the stability of the Czech crown against the Deutschmark over the last half of the decade is inconsistent with reported inflation rates during that period. ${ }^{9}$

Suppose, however, for the sake of argument we accept that biases are substantially smaller than our preliminary analysis suggests they are. The critical point that biases in the measurement of inflation will fundamentally alter our understanding of the transition still holds. The second column of Table 1 shows the compound annual growth rate between 1990 and 1999 as officially reported for seven major countries in transition as well as the number of years of negative growth for each country in parentheses. Columns 3

\footnotetext{
${ }^{8}$ These items count for about 17.5 percent of the Czech consumer price index bundle and a far larger proportion of inflation.

${ }^{9}$ At the start of January 1995 the exchange rate was 17.93 crowns to the DM while at the beginning of September 2000 it was 18.09 although the reported increase in consumer prices during the same period was over 50 percent while prices in Germany remained essentially stable.
} 
through 6 show what the average annual growth rate and number of years of negative growth would have been if inflation were biased by between 10, 15, 20 or 25 percent. Each of these bias levels is significantly lower than the up-to-50 percent bias our calculations presented above suggest is possible for the Czech Republic. Similarly they are even lower than the bias commonly believed to exist in the U.S. and other OECD countries. They presumably imply rates of unmeasured productivity growth that Brada. et al. would find more reasonable. Even at these levels of bias, the growth experience of the transition economies is very different from the conventional wisdom. Suppose, again for the sake of argument, that the CPI in transition economies is overstated by a mere 20 percent, less than the level of bias found in the U.S. and far less than half of the upperbound estimate that Brada et al. find unrealistic. If inflation measures are biased by even this little, eliminating the bias would show that every country in the region grew during the 1990s, turning a story of decline and disruption into one of growth and hope.

While we remain agnostic as to the true inflation rate, we are convinced that biases in officially reported measures of price increases mean that economists and policy makers should be extremely cautious in analyzing macroeconomic developments during the transition. When technical adjustments in data collection techniques can fundamentally alter the story being told, one should not place undue emphasis on policy recommendations derived from that story. 


\section{References}

Banse, Martin and Stephan Brosig, "Estimated demand systems for Hungary, Poland and the Czech Republic", working paper 1/4, Institute of Agricultural Economics, Göttingen, 1998.

Brada, Josef C., Arthur E. King, and Ali M. Kutan, "Inflation bias and productivity shocks in transition economies: The case of the Czech Republic", Economic Systems, 24: 2, 2000, pp. 119-138.

Boskin, Michael J., E. Dulberger, R. Gordon, Z. Griliches, and D. Jorgenson, “Toward a more accurate measure of the cost of living”, research report, The Senate Finance Committee, December 1996.

Dahlen, J., "Sensitivity analysis for harmonizing European consumer price indices", photocopy, Statistics Canada, Ottawa, 1994.

De Broeck, Mark and Vincent Koen, "The great contraction in Russia, the Baltics and the other countries of the former Soviet Union: A view from the supply side”, working paper 00/32, The International Monetary Fund, Washington, DC, 2000.

Diewert, Erwin W., "Exact and superlative index numbers”, Journal of Econometrics, 4, 1976, pp. 115-145.

Diewert, Erwin W., “Axiomatic and economic approaches to elementary price indexes”, discussion paper 9501, University of British Columbia Department of Economics, Vancouver, 1995.

Diewert, Erwin W., "Index number issues in the consumer price index", Journal of Economic Perspectives, 12, 1998, pp. 47-58. 
Dornbusch, Rudiger and Stanley Fischer, "Moderate inflation", The World Bank Economic Review, 7, 1, 1993, pp. 1-44.

European Bank for Reconstruction and Development, Transition Report, London, EBRD, 1999.

Fisher, Irving, The Making of Index Numbers, Boston, Houghton-Mifflin, 1922.

Gylfason, Thorvaldur and Tryggvi Thor Herbertsson, “Does inflation matter for growth?”, discussion paper, 1503, CEPR, London, 1996.

Hoffmann, Johannes, "Problems of inflation measurement in Germany: An update", research paper, Deutsche Bundesbank, Frankfurt, 1999.

Koen, Vincent, "Price measurement and mismeasurement in Central Asia", working paper 95/82, The International Monetary Fund, Washington, DC, 1995.

Koen, Vincent and Paula De Masi, "Prices in transition: Ten stylized facts”, working paper, 97/158, The International Monetary Fund, Washington, DC, 1997.

Könus, Alexander Alexandrovich, "The problem of the true index of the cost of living", Econometrica, 7 , 1939, pp. 10-29.

Kornai, Janos, Struggle and Hope: Essays on Stabilization in a Post-socialist Economy, Cheltenham, Edward Elgar, 1997. 
Lipton, David, and Jeffrey Sachs, "Creating a market economy in Eastern Europe: The case of Poland", Brookings Papers on Economic Activity, 1, 1990, pp. 74-147.

Lloyd, P. J., "Substitution effects and biases in nontrue price indices”, American Economic Review, 65, 1975, pp. 301-313.

Oulton, N., "Do UK price indexes overstate inflation?", National Institute Economic Review, 152, 1995, pp. $60-75$.

Pollak, Robert A., “The social cost of living index", Journal of Public Economics, 15, 1981, pp. 311-336.

Stiglitz, Joseph E., Whither Socialism?, Cambridge, MA, MIT Press, 1994.

Winiecki, Jan, "The inevitable fall in output in the early stages of transition to the market: Theoretical underpinnings", Soviet Studies, 43, 1991, pp. 669-676.

Woolford, K., "A pragmatic approach to the selection of appropriate index formulae", photocopy, Statistics Canada, Ottawa, 1994. 


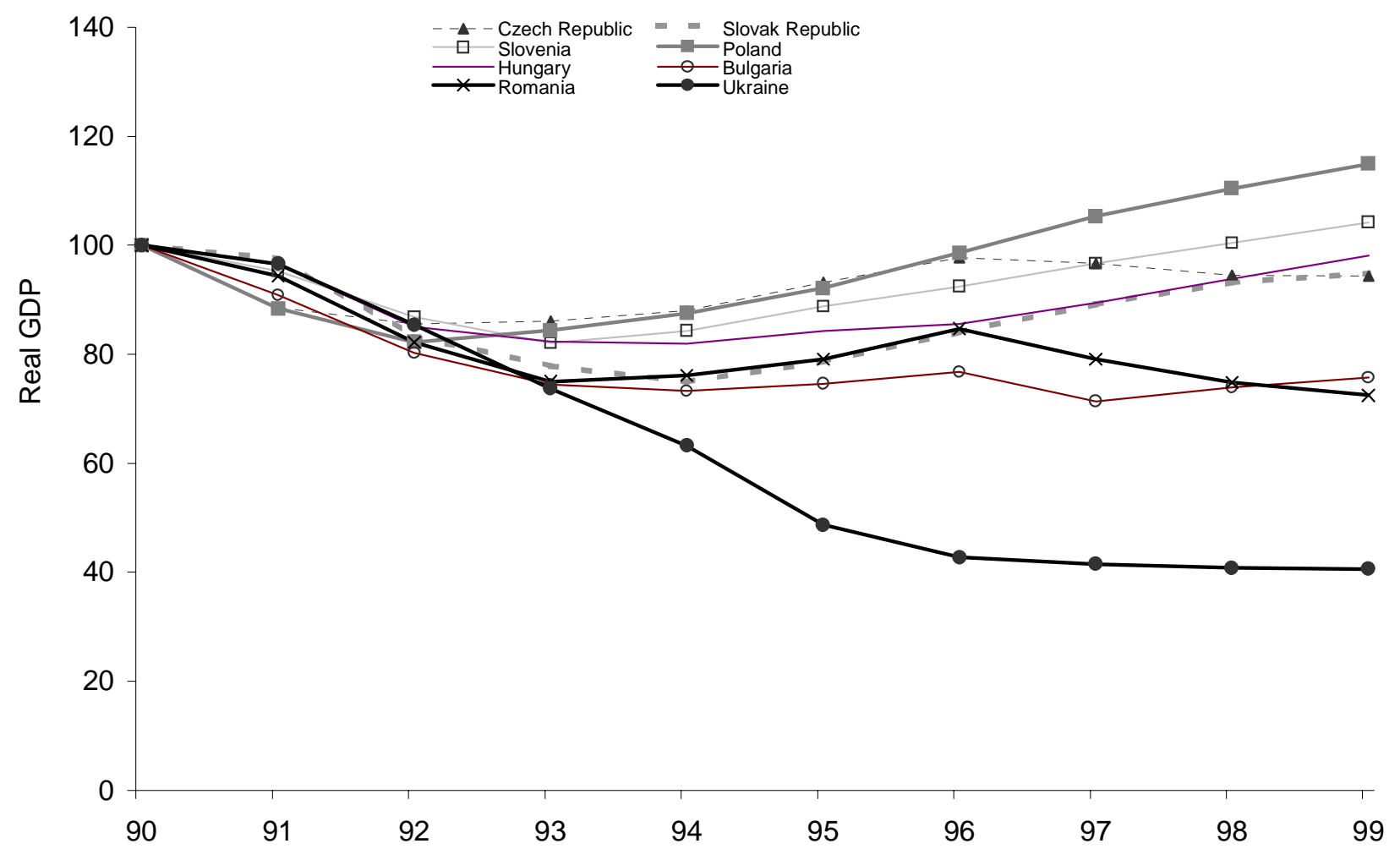

FIGURE 1

Real GDP during transition 


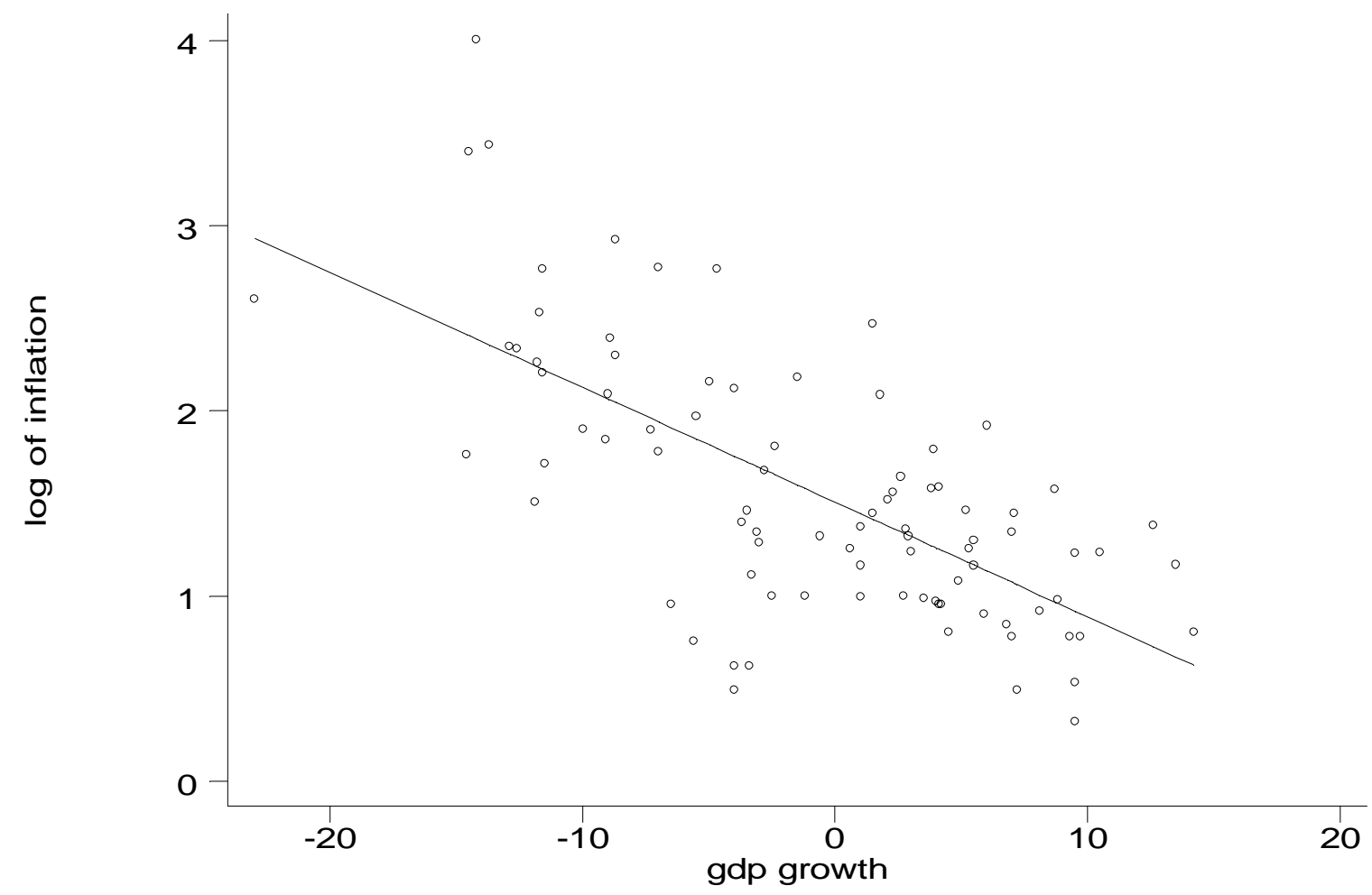

FIGURE 2

Relationship between reported inflation and real GDP growth 


\begin{tabular}{|c|c|c|c|c|c|}
\hline & $\begin{array}{c}\text { As Officially } \\
\text { Reported }\end{array}$ & $\begin{array}{c}\text { If Inflation } \\
\text { Overstated } \\
\text { by } 10 \% \\
\end{array}$ & $\begin{array}{c}\text { If Inflation } \\
\text { Overstated } \\
\text { by } 15 \% \\
\end{array}$ & $\begin{array}{c}\text { If Inflation } \\
\text { Overstated } \\
\text { by } 20 \% \\
\end{array}$ & $\begin{array}{c}\text { If Inflation } \\
\text { Overstated } \\
\text { by } 25 \% \\
\end{array}$ \\
\hline Bulgaria & $\begin{array}{c}-3.8 \% \\
(6)\end{array}$ & $\begin{array}{c}0.7 \% \\
(4)\end{array}$ & $\begin{array}{l}3.1 \% \\
(4)\end{array}$ & $\begin{array}{l}5.6 \% \\
(1)\end{array}$ & $\begin{array}{c}8.3 \% \\
(1)\end{array}$ \\
\hline $\begin{array}{l}\text { Czech } \\
\text { Republic }\end{array}$ & $\begin{array}{c}-0.7 \% \\
(6)\end{array}$ & $\begin{array}{c}0.5 \% \\
(4)\end{array}$ & $\begin{array}{l}1.2 \% \\
(3)\end{array}$ & $\begin{array}{l}1.8 \% \\
(3)\end{array}$ & $\begin{array}{l}2.5 \% \\
(2)\end{array}$ \\
\hline Hungary & $\begin{array}{c}-0.1 \% \\
(4) \\
\end{array}$ & $\begin{array}{r}1.8 \% \\
(3) \\
\end{array}$ & $\begin{array}{r}2.7 \% \\
(3) \\
\end{array}$ & $\begin{array}{c}3.7 \% \\
(1) \\
\end{array}$ & $\begin{array}{r}4.6 \% \\
(1) \\
\end{array}$ \\
\hline Poland & $\begin{array}{c}2.0 \% \\
(2)\end{array}$ & $\begin{array}{c}4.9 \% \\
(2)\end{array}$ & $\begin{array}{l}6.5 \% \\
(1)\end{array}$ & $\begin{array}{c}8.1 \% \\
(0)\end{array}$ & $\begin{array}{c}9.8 \% \\
(0)\end{array}$ \\
\hline Romania & $\begin{array}{c}-2.8 \% \\
(6) \\
\end{array}$ & $\begin{array}{l}1.8 \% \\
(6)\end{array}$ & $\begin{array}{l}4.3 \% \\
(2)\end{array}$ & $\begin{array}{c}6.9 \% \\
(2)\end{array}$ & $\begin{array}{c}9.6 \% \\
(1)\end{array}$ \\
\hline Russia & $\begin{array}{c}-5.4 \% \\
(8)\end{array}$ & $\begin{array}{c}-0.5 \% \\
(6)\end{array}$ & $\begin{array}{l}2.2 \% \\
(4)\end{array}$ & $\begin{array}{l}5.1 \% \\
(2)\end{array}$ & $\begin{array}{c}8.2 \% \\
(1)\end{array}$ \\
\hline Ukraine & $\begin{array}{c}-9.6 \% \\
(10)\end{array}$ & $\begin{array}{c}-4.8 \% \\
(9)\end{array}$ & $\begin{array}{c}-2.1 \% \\
(7)\end{array}$ & $\begin{array}{r}0.7 \% \\
(5)\end{array}$ & $\begin{array}{c}3.8 \% \\
(2)\end{array}$ \\
\hline
\end{tabular}

Source: Authors' calculations from raw data provided by EBRD

TABLE 1

Effect of Bias in CPI on Cumulative Annual Growth Rate: 1990-1999

(Number of years of negative growth in parentheses) 